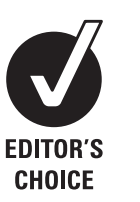

Physicians for a Smoke-Free Canada, Ottawa, Ontario, Canada

\section{Correspondence to} Cynthia Callard, Physicians for a Smoke-Free Canada, 1226 A Wellington Street, Ottawa Ontario, Canada K1Y 3A1 ccallard@smoke-free.ca

Received 27 November 2009 Revised 3 March 2010 Accepted 22 March 2010

\title{
Follow the money: How the billions of dollars that flow from smokers in poor nations to companies in rich nations greatly exceed funding for global tobacco control and what might be done about it
}

\author{
Cynthia Callard
}

\begin{abstract}
The business of selling cigarettes is increasingly concentrated in the hands of five tobacco companies that collectively control almost $90 \%$ of the world's cigarette market, four of which are publicly traded corporations. The economic activities of these cigarette manufacturers can be monitored through their reports to shareholders and other public documents. Reports for 2008 show that the revenues of these five companies exceeded $\$ 300$ billion, of which more than $\$ 160$ billion was provided to governments as taxes, and that corporate earnings of the four publicly traded companies were over $\$ 25$ billion, of which $\$ 14$ billion was retained after corporate income taxes were paid. By contrast, funding for domestic and international tobacco control is not reliably reported. Estimated funding for global tobacco control in 2008 , at $\$ 240$ million, is significantly lower than resources provided to address other highmortality global health challenges. Tobacco control has not yet benefited from the innovative finance mechanisms that are in place for HIV/AIDS, tuberculosis and malaria. The Framework Convention On Tobacco Control (FCTC) process could be used to redirect some of the earnings from transnational tobacco sales to fund FCTC implementation or other global health efforts.
\end{abstract}

\section{INTRODUCTION}

Tobacco use is a global health problem, and the business activities which fuel tobacco use have garnered strength from the economic, cultural and trade dimensions of globalisation. ${ }^{1}$

Indicative of the increased globalisation of the tobacco market is the extent to which domestic tobacco producers have been replaced by multinational corporations. While it may be difficult to visualise the number of smokers worldwide (1.3 billion) or the number of cigarettes smoked in recent years (5.6 trillion in 2008), ${ }^{2}$ the number of tobacco companies that make most of these cigarettes can be can be counted on the fingers of one hand. They are British American Tobacco, the China National Tobacco Company, Imperial Tobacco, Japan Tobacco and Philip Morris International. Among the companies that have in recent years been acquired by or merged with these companies are Gallaher, Lakson, Reemstma, Rothmans, Sampoerna, SEITA, Tabacalera and Tekel. ${ }^{3}$ In only a few nations (such as China, the USA, Japan, Thailand, Egypt) is the tobacco market operated by companies headquartered in that country, ${ }^{3}$ and the global market share of multinational tobacco companies has grown significantly over the past two decades (table 1).

The world's largest tobacco company is owned and controlled by the Chinese government and operates almost exclusively in China; in 2008 it accounted for $38 \%$ of the world's cigarette sales. ${ }^{5}$ While estimates differ of the market share of the largest companies operating outside China, ${ }^{8-10}$ Euromonitor ${ }^{2}$ reports a further $50 \%$ of the world market is supplied by: British American Tobacco and its associates, (16.4\% global market share when sales by associated companies like Reynolds American are included); Philip Morris International (15.5\%); Japan Tobacco (10.9\%); and Imperial Tobacco $(5.9 \%)$. The remaining market is served by companies which operate predominantly in domestic or regional markets, such as US-based Altria/Philip Morris USA (3\%) and Lorillard ( $<1 \%$ ); Egypt's Eastern Tobacco (1.2\%); Korea's KT\&G (1.8\%); the Thai Tobacco Monopoly; the Taiwan Tobacco \& Liquor Corporation; the Vietnam National Tobacco Corporation; and Bulgaria's Bulgartabac (all under 1\%). ${ }^{211-13}$

One consequence of global concentration is the relative ease of measuring the tobacco economy by using information provided to shareholders and financial analysts in compliance with stock exchange and other regulations. Comparative data on tobacco control are less robust or routine but, nonetheless, allows comparison between the financial benefits to tobacco company owners that result from tobacco use and the financial resources provided by governments and others to reduce tobacco use.

\section{METHODS}

Sales data, revenue and income of the largest publicly traded tobacco companies for the 2008 fiscal year were collected from corporate annual reports of the companies reviewed, ${ }^{14-17}$ investor presentations ${ }^{8-10} 18$ and from other trade sources. $^{2} 31920$ Information on expenditures on tobacco control and selected health issues during this same general time period were gathered from publicly available sources. ${ }^{15} 16$ These data were compiled to provide a snapshot of the global economies of tobacco sales and tobacco control in 2007 and 2008.

Some adjustments to the data were required to allow for comparability. The companies reviewed defined key financial terms differently, reported on different time periods, presented data in different 
Table 1 Global cigarette market share, major companies, 1991 and 2008

\begin{tabular}{|c|c|c|c|c|}
\hline & \multicolumn{2}{|l|}{$1991^{4}$} & \multicolumn{2}{|l|}{$2008^{25-7}$} \\
\hline & $\begin{array}{l}\text { Billion } \\
\text { cigarettes }\end{array}$ & $\begin{array}{l}\text { Share of } \\
\text { global market } \\
(\%)\end{array}$ & $\begin{array}{l}\text { Billion } \\
\text { cigarettes }\end{array}$ & $\begin{array}{l}\text { Share of } \\
\text { global market } \\
\text { (\%) }\end{array}$ \\
\hline $\begin{array}{l}\text { China National Tobacco } \\
\text { Company (CNTC) }\end{array}$ & 1687 & 32.0 & 2143 & 38.3 \\
\hline Philip Morris International & 640 & 12.2 & 869 & 15.5 \\
\hline Altria/Philip Morris USA & & & 169 & 3.0 \\
\hline $\begin{array}{l}\text { BAT (and Canada's Imperial } \\
\text { and India's ITC) }\end{array}$ & 529 & 10.1 & 830 & 14.8 \\
\hline Japan Tobacco & 275 & 5.2 & 612 & 10.9 \\
\hline $\begin{array}{l}\text { RJ Reynolds/Reynolds } \\
\text { American† }\end{array}$ & 135 & 2.6 & 90 & 1.6 \\
\hline Rothmans International & 120 & 2.3 & * & \\
\hline $\begin{array}{l}\text { Korea Tobacco and Ginseng } \\
\text { (South Korea) }\end{array}$ & 90 & 1.7 & 102 & 1.8 \\
\hline Bulgartabac (Bulgaria) & 80 & 1.5 & 13 & 0.2 \\
\hline American Brands & 78 & 1.5 & * & \\
\hline Tekel (Turkey) & 58 & 1.1 & * & \\
\hline Tabacalera (Spain) & 57 & 1.1 & * & \\
\hline Eastern Tobacco (Egypt) & 54 & 1.0 & 68 & 1.2 \\
\hline Reemtsma (Germany) & 53 & 1.0 & * & \\
\hline Seita (France) & 50 & 0.9 & * & \\
\hline AAMS (Italy) & 47 & 0.9 & * & \\
\hline Thailand Tobacco Monopoly & y 38 & 0.7 & 22 & 0.4 \\
\hline Lorillard & 37 & 0.7 & 37 & 0.7 \\
\hline Imperial (UK) & 32 & 0.6 & 329 & 5.9 \\
\hline Austria Tabak (SM) & 21 & 0.4 & * & \\
\hline Others & 1189 & 23 & 259 & 4.6 \\
\hline Total & 5267 & 100 & 5600 & 100 \\
\hline
\end{tabular}

currencies and used different regional groupings for their markets. To allow for better comparison of data:

- The terms (a) revenues, (b) earnings and (c) profits were used to mean (a) gross value of tobacco sales including excise taxes, (b) value of tobacco sales after costs of production and excise taxes have been subtracted and (c) net corporate proceeds after income taxes, extraordinary items and other expenses have been subtracted.

- The business activities reviewed were those in the fiscal year with the most months in 2008: that is the fiscal years ending 30 September 2008 (Imperial Tobacco), 31 December 2008 (British American Tobacco, Altria and Philip Morris International) and 31 March 2009 (Japan Tobacco).

- No adjustment was made to regional or geographical categories or terms, which are presented as provided by the companies. Information on the groupings used by the companies, although often vague can be found in their annual reports. ${ }^{14-17}$

- For companies that did not report results in US dollars, local currencies were converted to US dollars at the average annual rate in 2008, as stated in table 2 .

- This study is limited to the sale of manufactured cigarettes and fine-cut tobacco intended for use in cigarette form (ie, $\mathrm{RYO} /$ roll-your-own). These two product categories were combined by calculating $0.7 \mathrm{~g}$ of fine-cut tobacco as equivalent to a manufactured cigarette. Oral tobacco, shisha tobacco, pipe tobacco, bidis, etc, were not included in this study.

\section{RESULTS}

In 2008, British American Tobacco, Philip Morris International, Japan Tobacco International and the Imperial Tobacco Group shared about $\$ 220$ billion in revenues from tobacco sales. After these companies paid their production costs and remitted tobacco taxes to governments, their earnings were $\$ 25$ billion, approximately $\$ 0.18$ for each package of 20 cigarettes they sold. After paying corporate income taxes and other such expenses, they retained almost $\$ 14$ billion in profits (about $\$ 0.10$ per package). Almost nine-tenths of the sales on which these earnings were based were in foreign markets - that is, from sales in countries other than the country in which the company is officially and operationally headquartered. On average, each carton of 200 cigarettes sold by Philip Morris International resulted in a return of $\$ 2.30$, while Imperial Tobacco's earnings on foreign sales were $\$ 1.78$ per carton, BAT's were $\$ 1.60$ and Japan Tobacco's were $\$ 1.10$ per carton. These results are presented in table $2 .{ }^{14-17}$

\section{Results by company}

\section{China's National Tobacco Company (CNTC) ${ }^{5}$}

Chinese smokers consume $38 \%$ of the world's cigarettes, and the 2143 billion cigarettes they smoked in 2008 were all sold through the State Tobacco Monopoly Administration (STMA), and were almost all manufactured by the China National Tobacco Corporation (CNTC) which functions as an umbrella agency for China's many domestic companies. Like its multinational counterparts, the Chinese tobacco industry is undergoing significant restructuring. The CNTC sold relatively few (13 billion) cigarettes outside China in 2008, although it has announced intentions to expand its foreign trade, and has entered an agreement with Philip Morris International to distribute its 'heritage' brands in international markets. ${ }^{23} 24$ Many distinctions between the operations and reporting of CNTC and the publicly traded multinationals make it inappropriate to compare business results with other companies. Euromonitor reports that in 2008 the total tax revenue of the Chinese industry was $\$ 64$ billion (CNY (Chinese yuan renminbi) 450 billion) and that the value of sales was $\$ 105$ million (CNY 732).

\section{British American Tobacco (BAT) ${ }^{15}$}

BAT is based in the UK but, for historical business and legal reasons, has a much smaller presence in the UK and operates indirectly (through, Reynolds American) in the USA. In 2008, it directly managed the manufacture and sale of 716 billion cigarettes and through the associated companies in which it is the largest shareholder, it indirectly managed the sale of an additional 204 billion cigarettes. BAT claims to sell three-quarters of its production in developing countries. Transnational earnings from BAT's global operations exceeded \$7 billion in 2008 .

\section{Philip Morris International (PMI) ${ }^{19}$}

Philip Morris brands have been sold internationally for decades, but Philip Morris International (PMI) was created as recently as 2008, when it was spun off from Altria. Although PMI has its operating headquarters in Switzerland, its legal headquarters is in the USA. PMI and Altria continue to operate in tandem: the brands that are sold by Altria in the USA are sold in other parts of the world by PMI, ${ }^{13}$ including the world's best-selling cigarette, Marlboro, which has 13\% market share of the cigarettes sold outside China. ${ }^{18}$ In 2008, Philip Morris International sold 870 billion cigarettes and its earnings exceeded $\$ 10$ billion. Fewer than half its sales were in OECD member countries. 
Table 2 Sales, revenues, earnings and profits of the CNTC and major tobacco multinational tobacco companies, $2008 \dagger$

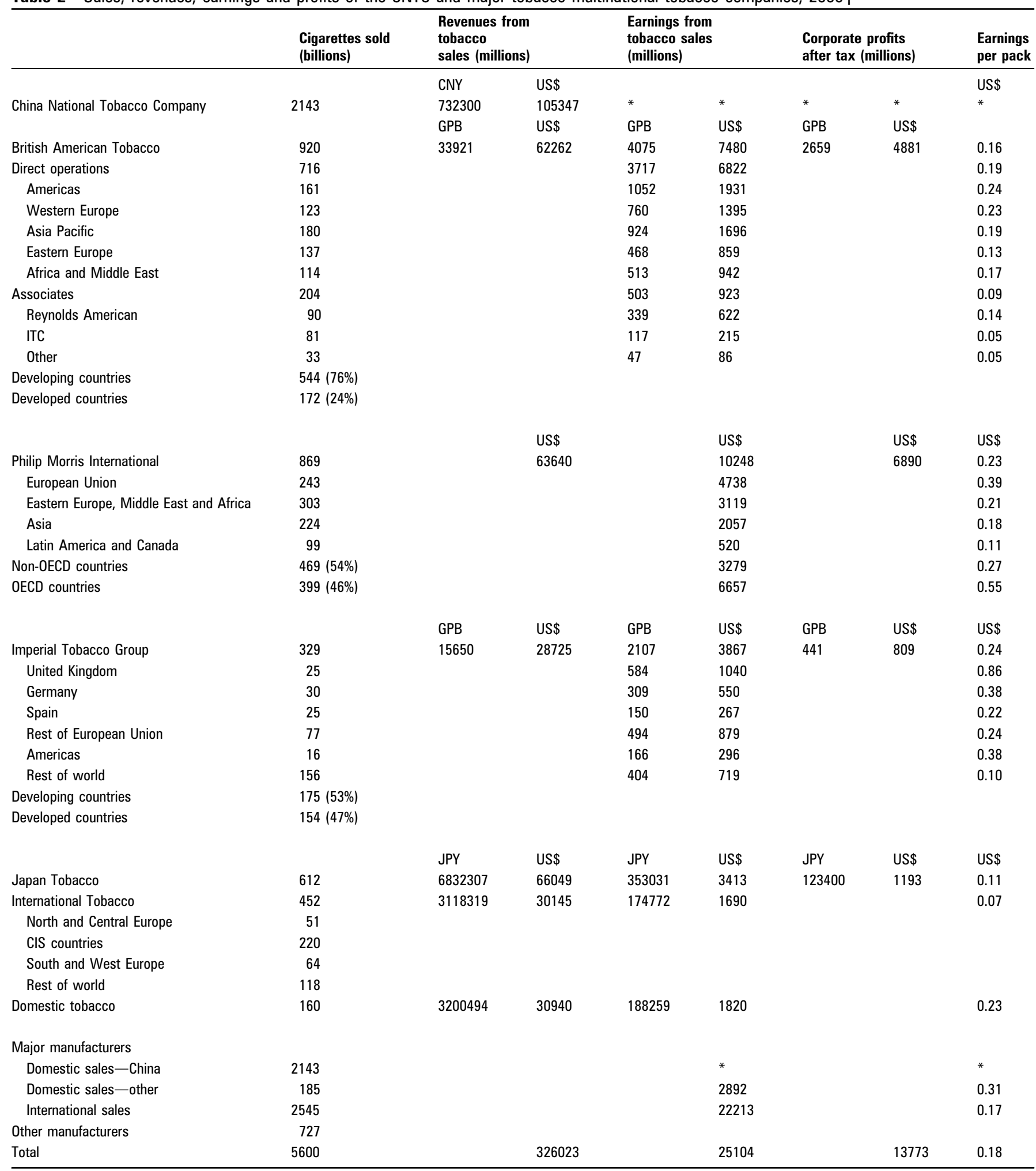

*Comparable figures not available.

†Currency converted at the yearly average rates $(\mathrm{US} \$=1 ; \mathrm{CNY}=6.95 ; \mathrm{GBP}=0.55 ; \mathrm{JNY}=103.4$ ).

The Imperial Group (ITG) ${ }^{16}$

For many years, the Imperial Tobacco Group PLC (ITG) sold few cigarettes outside the UK, but in recent years it has globalised its business through the acquisition of other companies, such as Reemtsma, Altadis and Commonwealth Brands. In 2008 only 25 billion of its total sales of 329 billion cigarettes were in the UK.
ITG's sales are concentrated in the Americas and Europe, with only one-fifth of its market outside these continents, but almost half of its sales are in developing countries and newly industrialised states (particularly eastern Europe). Earnings from Imperial Tobacco's global operations approached $\$ 3$ billion in 2008, with a further $\$ 1$ billion in earnings from the UK. 


\section{Japan Tobacco (JT) $)^{1425}$}

Almost three-quarters of the 613 billion cigarette manufactured and sold by Japan Tobacco in 2008 were sold through its wholly owned subsidiary, Japan Tobacco International. Although JT is a publicly traded company, the Japanese government holds a 50\% ownership and the legal authority to supervise its operations. Japan Tobacco also maintains non-tobacco operations, including pharmaceutical products and food, but less than $5 \%$ of its earnings come from these other sources. Transnational earnings from Japan Tobacco's international operations were $\$ 1.7$ billion in 2008, and its domestic tobacco earnings were $\$ 1.8$ billion.

\section{Government revenues from tobacco}

From the sale of cigarettes made by the four largest tobacco multinationals, governments received over $\$ 100$ billion in tobacco specific taxes and almost $\$ 7$ billion in corporate income taxes. ${ }^{14-17}$ Total payments to government exceed $\$ 170$ billion when payments by other tobacco companies are included. ${ }^{12} 131926$ These tax payments, as reported in the annual reports are displayed in table 3, although company reports do not state to which government these taxes were remitted.

In addition to tax revenues, governments which have complete or partial ownership in tobacco companies receive income in the form of remittances or dividend payments. This will occur when the government owns and controls a state monopoly, such as Egypt's Eastern Company, Vietnam's VINATABA, Thailand's Tobacco Monopoly and Taiwan's Tobacco \& Liquor Corporation. Governments which do not own state monopolies may own shares in publicly traded tobacco companies, and will receive dividend payments or other forms of profit sharing from these investments. On the basis of the holdings by the government of Japan in Japan Tobacco, it likely received $\$ 275$ million in dividend payments for 2008, about half of which was attributable to profits on international tobacco sales. ${ }^{14}$ Governments may invest in tobacco companies headquartered in other countries; public pension investments by governments of Canada and the Canadian province of Quebec are estimated to have resulted in combined dividend payments totalling $\$ 20$ million from the profits of international tobacco sales in $2008 .^{27}$

\section{Government investments in domestic and global tobacco control} Estimates of government expenditures on tobacco control suffer from several methodological constraints. In 2007 and again in 2008, the WHO Tobacco Free Initiative (WHO/TFI) requested member states to report expenditures on national tobacco control programmes. ${ }^{21} 28$ In the first report, fewer than half of WHO member states provided information on their tobacco control expenditures and in the second report the response rate was still below $60 \%$. The WHO nonetheless estimated that governments 'spent a total of $\$ 965$ million on tobacco control-with $99 \%$ of this amount spent by 17 high income countries. ${ }^{27}$ Whether or not this sum included funding by subnational governments or funds for international programming is not made clear.

The challenges faced by WHO/TFI in gathering data on global funding for national tobacco control programmes is paralleled by challenges the Framework Convention on Tobacco Control (FCTC) Secretariat faced in gathering data on funding for global tobacco control, such as the development assistance for health (DAH) provided by governmental or private organisations or individuals. After attempting to quantify this support in 2005 , the WHO FCTC Secretariat concluded it was 'impossible to provide a clear indication of the amounts of funding available. ${ }^{29}$ Although parties to the FCTC are required to report whether they received or provided financial or other forms of assistance, they are not required to quantify this support. ${ }^{30}$

One of the most active supporters of global tobacco control, the Bloomberg Philanthropies, suggested in 2007 that \$200 million was spent on international development aid for tobacco control. ${ }^{22}$ The basis for their estimate was not stated, but it may have included the annual budget for the functioning of the Framework Convention on Tobacco Control (now \$6.5 million), ${ }^{31}$ the portion of the WHO budget for tobacco, alcohol, unhealthy diets, physical activity and unsafe sex (the total of which is now $\$ 80$ million) that is spent on tobacco control, ${ }^{32}$ and the estimated annual $\$ 62$ million investment of the Bloomberg Initiative to Reduce Tobacco Use. ${ }^{33}$ Since that estimate was made, a further $\$ 25$ million annualised donation was announced in 2008 by the Bill and Melinda Gates Foundation, ${ }^{34}$ and WHO/TFI produced an estimate of $\$ 9.6$ million spent on national tobacco control programmes in middle-income and low-income countries. Based on these available estimates, the total available for development assistance for tobacco control is likely no greater than $\$ 240$ million.

\section{Comparison with development assistance for health to control other diseases}

Investments in international assistance for tobacco control from both governmental and private sources is much smaller than investments in other identified global health challenges, on both an absolute and relative basis. A recent review of DAH estimated the total 'financial and in-kind contributions from global health channels that aim to improve health in developing countries' between 1990 and 2007. ${ }^{35}$ This study identified support for HIV/AIDS, tuberculosis and malaria, but did not provide estimates for development assistance for tobacco control. Using the adjusted estimate of DAH for tobacco control provided by the Bloomberg Foundation, discussed above, and combining measures of DAH with estimates of the current and future burden of these diseases ${ }^{36} 37$ shows that DAH for each person living with HIV/AIDS (\$111 per year), or tuberculosis $(\$ 50)$ far exceeds the amount provided for each person who smokes (\$0.25). (Global estimates for malaria cases are not available.) When investments in preventable disease control are measured against predicted deaths in $2030,{ }^{38}$ the funding for malaria (\$1189), for tuberculosis (\$1127), and HIV/AIDS (\$782) again greatly exceed the funding to prevent tobacco-caused disease (\$35). These results are shown in table 4.

Tobacco control has not benefited, as have other diseases with large global mortality, from the development of new mechanisms to provide financial development assistance for health, such as the Global Fund to Fight AIDS, Tuberculosis and Malaria (GFATM) and the Global Alliance for Vaccines and Immunisation (GAVI). Nor have innovative fund raising programmes to finance such instruments been developed for tobacco control as they have been developed for other global diseases during recent years. Such programmes include: the Advance Market Commitment for Vaccines (AMC), ${ }^{41}$ which uses price guarantees as incentives to for corporations to develop vaccines for diseases found in low-income countries; the International Finance Facility for Immunisation (IFFIm), which issues bonds in the capital market to raise funds for immunisation ${ }^{42}$; UNITAID, which buys drugs with monies raised through taxes on air tickets and other revenues ${ }^{43}$; Bono and Bobby Shriver's private-sector cause-marketing project (RED), which provides 
Table 3 Taxes remitted by largest tobacco companies, 2008 (millions)

\begin{tabular}{|c|c|c|c|c|c|c|c|}
\hline Company & $\begin{array}{l}\text { Fiscal year } \\
\text { end }\end{array}$ & $\begin{array}{l}\text { Global market } \\
\text { share }\end{array}$ & Tobacco taxes & & Income taxes & & Total \\
\hline & & & & US\$ & & US\$ & US\$ \\
\hline China National Tobacco Company (CNTC) & 31-Dec-08 & $38 \%$ & CNY 449900 & 71915 & $\dagger$ & & 71915 \\
\hline Philip Morris International (PMI) & 31-Dec-08 & $15.5 \%$ & & 3935 & & 2787 & 6722 \\
\hline Japan Tobacco (JTI) & 31-Mar-09 & $10.9 \%$ & JNY 2016019 & 19489 & JNY 199759 & 1931 & 21420 \\
\hline Imperial Tobacco Group (ITG) & 30-Sep-08 & $5.9 \%$ & GBP 10412 & 19111 & GBP 180 & 330 & 19441 \\
\hline Reynolds American & 31-Dec-08 & * & & 1890 & & 790 & 2680 \\
\hline Lorillard & 31-Dec-08 & $<1 \%$ & & 712 & & 547 & 1259 \\
\hline Total & & $91 \%$ & & 161,642 & & 9,966 & 171,608 \\
\hline
\end{tabular}

*Included with BAT total.

†Not available or not found.

a portion of earnings from the sale of consumer goods to AIDS projects in Africa ${ }^{44}$; and the Debt2Health, which allows borrowing and lending nations to make debt-swaps to free up domestic resources to address HIV/AIDS, tuberculosis and malaria. ${ }^{45}$

\section{DISCUSSION}

The globalisation of the tobacco market has resulted in significant transnational transfers of revenues from tobacco sales. The globalisation of tobacco control, in the form of the FCTC, has not yet resulted in significant transnational transfers of revenues to support tobacco control efforts.

Global concentration of the tobacco industry could allow for increased funds to be made available for global efforts to reduce tobacco use through the use of transaction taxes on the flow of profits from countries where multinational tobacco companies sell cigarettes to countries where they distribute the profits or other fiscal instruments. This could reverse the current pattern, which sees money flow from smokers in developing countries to corporations in the developed world. It would also be consistent with the 'polluter pay' principle and with proposals like the Tobin Tax to levy fines on international financial transactions. A precedent for surtaxes on tobacco companies can be found in Canada, where the government levied a 'health promotion surtax $^{46}$ on tobacco manufacturers' earnings in 1994, now set at $150 \%$ of the tax rate for all other corporations. ${ }^{47}$
The imbalance between the money that flows from (often poor) smokers to (often not poor) shareholders and the money that flows from wealthy to poor countries to reduce tobacco use can be illustrated by comparing the earnings received by just one tobacco company from smokers in one sub-continent with the amount provide to help all poor nations combat tobacco use. In 2005, BAT reported to investors that it sold 40 billion cigarettes in two of the world's poorest regions, Equatorial and West Africa, and that a similar number of cigarettes were sold in the region by all other companies combined. ${ }^{48}$ Assuming the profits on BAT's sales in that region were consistent with its average earnings that region ( $\$ 0.17$ per package of 20 cigarettes, shown in table 1), then smokers in the poorest countries of sub-Saharan Africa provided about $\$ 340$ million to BAT's bottom line, about $140 \%$ the global DAH for tobacco control. Equivalent figures for earnings from tobacco sales by other companies in that region are not disclosed, but would further increase the gap between the amount provided by Africans and the amount available to them.

The same governments and international agencies that have adopted innovative mechanisms and partnerships to raise funds for other global health challenges have so far failed to do so for tobacco, although they have developed in domestic tobacco control several models for how this could be done. Canada's health promotion surtax on tobacco manufacturers' income, mentioned above, is one available tax instrument. California Switzerland and other jurisdictions have imposed special

Table 4 Development assistance for control selected preventable disease

\begin{tabular}{|c|c|c|c|c|c|c|c|}
\hline & $\begin{array}{l}\text { DAH to developing } \\
\text { countries for } \\
\text { specific diseases } \\
\text { (2007) }\end{array}$ & $\begin{array}{l}\text { People living with } \\
\text { disease/smoking in } \\
\text { middle and low- } \\
\text { income countries }\end{array}$ & $\begin{array}{l}\text { DAH for every } \\
\text { person living with } \\
\text { specified disease } \\
\text { or smoking }\end{array}$ & $\begin{array}{l}\text { Estimated deaths } \\
2005 \text { in middle and } \\
\text { low-income } \\
\text { countries }\end{array}$ & $\begin{array}{l}\text { DAH per estimated } \\
\text { death in low and } \\
\text { middle-income } \\
\text { countries } 2005\end{array}$ & $\begin{array}{l}\text { Predicted deaths in } \\
\text { low and middle- } \\
\text { income countries } \\
2030\end{array}$ & $\begin{array}{l}\text { DAH per estimated } \\
\text { death in low and } \\
\text { middle-income } \\
\text { countries } 2030\end{array}$ \\
\hline & US\$ millions & & US\$ & Millions & US\$ & Millions & US\$ \\
\hline HIV/AIDS & 5068 & 45541113 & 111.28 & 2808545 & 1804.49 & 6478081 & 782.33 \\
\hline Source & 35 & 37 & & 38 & & 38 & \\
\hline Malaria & 761 & & & 887835 & 857.14 & 639940 & 1189.17 \\
\hline Source & 35 & & & 38 & & 38 & \\
\hline Tobacco use & 240 & 959000000 & 0.25 & 3800000 & 63.16 & 6800000 & 35.29 \\
\hline Source & 273039 & 36 & & 40 & & 40 & \\
\hline Tuberculosis & 687 & 13547995 & 50.71 & 1397407 & 491.62 & 609459 & 1127.23 \\
\hline Source & 35 & 37 & & 38 & & 38 & \\
\hline
\end{tabular}




\section{What this paper adds}

- Revenues generated through tobacco sales by multinational corporations can be monitored through corporate reports.

- Public investments to reduce tobacco use are extremely small compared with both corporate profits and government revenues from cigarette sales. They are also much smaller than public investments in other high-burden health issues.

- A mechanism to capture a share of the earnings on transnational tobacco sales could be developed through the Framework Convention on Tobacco Control and be used to increase available resources to reduce the burden of tobacco use.

consumption taxes on tobacco, or levies, to provide funding for tobacco control and other health programming. ${ }^{49} 50$

Governments could draw on the same innovative spirit they used to develop novel instruments to fund efforts against HIV/ AIDS, tuberculosis and malaria in order to find a suitable mechanism to increase funding available to development assistance for tobacco control. The experience with these other diseases suggests that when there is a political will, a way to raise money can be found.

The FCTC provides a forum appropriate for intergovernmental negotiation of ways to reduce the transboundary flow of earnings from tobacco use and to increase transboundary support for tobacco control. Actions the Conference of Parties and the FCTC Secretariat could take include:

- Monitoring the application of the Article 5.3 guidelines on tobacco industry influence which recommend against investments by governments in tobacco companies, and reporting on the dividends paid to governments that refuse to abide by these guidelines.

- Requesting parties to gather and report information on earnings of the tobacco industry in their country, and also to report on the destination of those earnings.

- Requesting WHO/TFI to include in its study of ways to implement FCTC Article 6 (tax and price) methods, currently under way, the use of profit taxes to raise funds for national and international tobacco control efforts.

Diverting a portion of the earnings on tobacco sales that cross international boundaries away from shareholders and towards the victims and potential victims of this commercial activity might be one way to resolve the funding crisis that hinders full implementation of the FCTC.

Funding Health Canada.

Competing interests None.

Provenance and peer review Not commissioned; externally peer reviewed.

\section{REFERENCES}

1. Pang T, Guindon GE. Globalization and risks to health. EMBO Rep 2007;5(Suppl 1): S11-16.

2. Euromonitor International. Global tobacco: survival strategies for a savage market. Euromonitor International, Chicago, 2008.

3. Hedley D. Riding the merry-go-round. Tob J Int 2008;74-76.

4. Euromonitor. The world market for tobacco: strategy 2000. Euromonitor, Chicago, 1993.

5. Euromonitor. Cigarettes-China. Euromonitor, Chicago, 2010.

6. Euromonitor. Tobacco. Euromonitor, Chicago, 2010. Eastern Company SAE, 2009

7. Euromonitor. Tobacco. Euromonitor, Chicago, 2010. Bulgaria: Bulgartabac Holding Group, 2010

8. British American Tobacco. Morgan Stanley Consumer Retail Conference; New York, 2008.

9. British American Tobacco. USD Global Bond Presentation, 2008.
10. Philip Morris International. A compelling investment, New York, 2008.

11. Demirsar M. Egypt's monopoly rakes in the profits, whetting the appetite of multinationals. Tob J Int. 2007;2:109-110.

12. KT\&G Corporation. Annual Report 2008. Seoul: KT\&G Corporation, 2008.

13. ALTRIA Group Inc. Form 10-K (Annual Report for 2008). New York: ALTRIA Group Inc, 2009.

14. Japan Tobacco Inc. Annual Report 2009. Tokyo: Japan Tobacco Inc, 2009.

15. British American Tobacco. Annual Report 2008. London: British American Tobacco, 2009.

16. Imperial Tobacco Group PLC. Annual Report and Accounts 2008. Bristol: Imperial Tobacco Group PLC, 2009.

17. Philip Morris International. Annual Report 2008. New York: Philip Morris International, 2009.

18. Philip Morris International. Presentation by Hermann Waldemer at the J.P. Morgan Global Tobacco Conference, 2009.

19. Matlick D. Thailand tobacco monopoly: more than a business. Tob Rep 2009;14-16.

20. China's Tobacco Industry Makes Progress in Development, Reform in 2008. Tobacco China Online. 2009. http://act.tobaccochina.net/englishnew/content1.aspx? id=37923 http://act.tobaccochina.net/englishnew/content1.aspx?id=37923 (accessed 15 Feb 2010)

21. World Health Organization. WHO Report on the Global Tobacco Epidemic, 2009 Geneva: World Health Organization, 2009

22. Henning KJ. Bloomberg initiative to reduce tobacco use. highlights and lessons learned. Istanbul: 12th World Congress on Public Health, 2009.

23. Anon. China to look for overseas mergers, acquisitions. Tob Rep 2009

24. Philip Morris International. Remarks for CAGNY Conference by Hermann Waldemer, CFO. Philip Morris International, 2009

25. Japan Tobacco Inc. Annual Report 2008. Tokyo: Japan Tobacco Inc, 2008.

26. Reynolds American Inc. Form 10-K (Annual Report for 2008). Winston Salem: Reynolds American Inc, 2009.

27. Physicians for a smoke-free Canada. Public pensions \& tobacco Canadian investments and revenue from global tobacco sales, Ottowa, 2008.

28. World Health Organization. WHO Report on the Global Tobacco Epidemic. 2008: The MPOWER package. Geneva: World Health Organization, 2008.

29. WHO Framework Convention on Tobacco Control Secretariat(FCTC Secretariat). Review of existing and potential sources and mechanisms of assistance. Geneva: A/FCTC/COP/1/4, 2006.

30. WHO Framework Convention on Tobacco Control. Reporting tools: Phase 1. Geneva: WHO Framework Convention on Tobacco Control, 2006

31. Decisions. Conference of the Parties to the WHO Framework Convention on Tobacco Control. Durban, 2008.

32. World Health Organization. World health assembly: proposed programme budget 2010-2011. Geneva: World Health Organization, 2009.

33. Bloomberg initiatives grant program. http://www.tobaccocontrolgrants.org (accessed 15 Feb2010).

34. Bill and Melinda Gates Foundation. Michael Bloomberg and Bill Gates join to combat global tobacco epidemic. Bill and Melinda Gates Foundation, 2008.

35. Institute for Health Metrics and Evaluation. Financing Global Health 2009 tracking development assistance for health. Seattle: University of Washington, 2009

36. Guindon GE, Boisclair D. Past, current and future trends in tobacco use. Health, Nutrition and Population Discussion Paper. Washington: International Bank for Reconstruction and Development / The World Bank, 2003.

37. World Health Organization. World Health Statistics. Geneva: World Health Organization, 2009.

38. Mathers CD, Loncar D. Projections of global mortality and burden of disease from 2002 to 2030. PLoS Medicine. 2006;3(11).

39. WHO Framework Convention on Tobacco Control Secretariat. Performance report for the 2006-2007 budget and workplan (decision FCTC/COP2(11)). Durban, South Africa: WHO Framework Convention on Tobacco Control Secretariat, 2008.

40. Mackay J, Eriksen M, Shafey 0. The tobacco atlas. 2nd edn. Atlanta, USA American Cancer Society, 2009.

41. Bill and Melinda Gates Foundation. Press Release: ive nations and the Bill \& Melinda Gates Foundation launch Advance Market Commitment for vaccines to combat deadly disease in poor nations. Bill and Melinda Gates Foundation, 2007.

42. International Finance Facility for Immunisation. IFFIm. http://www.iffimmunisation.org (accessed 20 Nov 2009).

43. World Health Organization. UNITAID Annual Report. Geneva: World Health Organization, 2008.

44. RED. Join red. http://www.joinred.com (accessed 20 Nov 2009)

45. Global Fund to Fight AIDS, Tuberculosis and Malaria. Seventeenth board meeting: report of the finance and audit committee. Geneva, 2008.

46. Parliament of Canada. House of commons Hansard. Ottawa: 1994

47. Government of Canada. Income Tax Act, Part II, c. 182: 2000

48. British American Tobacco. Analysts visit to Rome. Africa Middle East. 2005

49. Balbach ED, Traynor MP, Glantz SA. The implementation of California's tobacco tax initiative: the critical role of outsider strategies in protecting Proposition 99. J Health Polit Policy Law 2000;25:689-715.

50. Switzerland Federal Office of Public Health. Tobacco control Fund. http://www. bag.admin.ch/tabak praevention/index.html?lang=en http://www.bag.admin.ch/ tabak_praevention/index.html?lang=en (accessed 20 Nov 2009). 